\title{
Aimé Richardt, Érasme. Une intelligence au service de la paix
}

Préface de Mgr Huot-Pleuroux. Postface de Jean de France, duc de Vendôme. Paris, Lethielleux, 2010, 226 p.

\section{Willem Frijhoff}

\section{(2) OpenEdition} Journals

Édition électronique

URL : http://journals.openedition.org/assr/22946

DOI : $10.4000 /$ assr.22946

ISSN : $1777-5825$

Éditeur

Éditions de l'EHESS

Édition imprimée

Date de publication : 31 décembre 2011

Pagination : 265

ISBN : 9782713223273

ISSN : 0335-5985

Référence électronique

Willem Frijhoff, «Aimé Richardt, Érasme. Une intelligence au service de la paix », Archives de sciences sociales des religions [En ligne], 156 | octobre-décembre 2011, document 156-97, mis en ligne le 17 février 2012, consulté le 21 septembre 2020. URL : http://journals.openedition.org/assr/22946 ; DOI : https://doi.org/10.4000/assr.22946

Ce document a été généré automatiquement le 21 septembre 2020.

() Archives de sciences sociales des religions 


\section{Aimé Richardt, Érasme. Une intelligence au service de la paix}

Préface de Mgr Huot-Pleuroux. Postface de Jean de France, duc de Vendôme. Paris, Lethielleux, 2010, 226 p.

\section{Willem Frijhoff}

\section{RÉFÉRENCE}

Aimé Richardt, Érasme. Une intelligence au service de la paix, Préface de Mgr HuotPleuroux. Postface de Jean de France, duc de Vendôme. Paris, Lethielleux, 2010, 226 p.

1 Érasme est de ces érudits engagés dont l'éloquence élégante, la formule juste, le jugement sûr et souvent mordant ne laissent pas indifférent et parviennent encore à nous provoquer près de cinq siècles après sa mort. Bien des historiens, philosophes et théologiens, et écrivains de tous bords se sont évertués à brosser son portrait en bien ou en mal. Mais tous ont reconnu la singularité du personnage, son rôle prééminent dans les troubles religieux du $\mathrm{XVI}^{\mathrm{e}}$ siècle et sa position incontournable dans l'évolution des idées religieuses et des attitudes sociales, en particulier dans le combat pour la concorde dans l'Église. C'est cet Érasme, auteur public et protagoniste irénique dans les affaires religieuses, qu'Aimé Richardt nous brosse à grands traits dans cette biographie. Elle se présente comme le témoignage empathique et la découverte personnelle par l'auteur d'un important acteur de l'histoire dont l'image auprès du grand public fut longtemps ternie par l'accusation de luthéranisme, de la part de l'Église catholique, et de celle d'indécision et du refus d'assumer la conséquence de ses idées, de la part des protestants. A. Richardt s'inscrit tout particulièrement en faux contre l'accusation de luthéranisme. Pour la démonter, il emploie la méthode biographique plutôt que l'approche intellectuelle. Le lecteur suit Érasme dans le parcours de sa vie et de ses écrits, de sa naissance à Rotterdam, vers 1469, jusqu'à sa mort à Bâle, en 1536. Les étapes de sa vie sont illustrées de citations bien choisies, en particulier dans ses lettres. A. Richardt parvient à rendre sa thèse plausible, mais il en 
reste à cet Érasme chrétien public. Nous apprenons peu de son rôle public dans d'autres domaines, comme la défense des humanités (les bonae litterae), l'éducation, le combat pour la paix civile, ou la définition des normes de la vie sociale qu'Érasme voulait équilibrée et civilisée, même si tout cela est effleuré au détour de tel ou tel chapitre. L'Érasme privé, le "philosophe chrétien » imbu d'une piété active marquée par la Dévotion moderne, reste quelque peu dans l'ombre. Mais A. Richardt souligne à juste titre les défauts du personnage. Car Érasme était un célibataire rabâcheur, ambitieux et hypersensible au moindre mot critique, peu amène dans le commerce avec ses semblables, et neurasthénique à ses heures. Il n'emporte pas toujours notre sympathie, mais il a indiscutablement marqué son époque et réussit toujours à enthousiasmer nos contemporains au point de figurer comme icône de la démocratie, de la tolérance et, dans cette biographie, du pacifisme.

Comme d'autres ouvrages de cet auteur fécond en biographies et fresques historiques destinées au grand public, celui-ci, encadré par des éloges de la plume d'un prélat et d'un prince du sang, ne repose pas sur une recherche originale dans les sources d'époque ou les ouvrages et lettres d'Érasme en version latine. A. Richardt puise ses données exclusivement dans les traductions et dans les travaux des spécialistes d'Érasme, et sa thèse sur la place d'Érasme dans le débat sur le libre arbitre ne prétend nullement innover l'immense bibliographie existant à ce sujet. Il faut cependant reconnaître qu'il a eu la main heureuse dans ses choix. L'on reconnait en particulier l'inspiration des biographies empathiques d'Érasme par Stefan Zweig (1935), Léon Halkin (1987) et Jean-Claude Margolin (1995), tout comme l'Érasme hérétique de Silvana Seidel Menchi (1996) sur le sort qui lui a été fait par l'inquisition romaine. Proposant un Érasme vivant et véridique, un des premiers intellectuels dans le sens actuel du terme, A. Richard réussit à montrer dans cet ouvrage de vulgarisation réussi en quoi un intellectuel $\mathrm{du} \mathrm{xVI}^{\mathrm{e}}$ siècle peut encore passionner nos contemporains. C'est effectivement l'approche biographique qui permet le mieux d'approprier le sens de ses actions et leur valeur d'exemple durable par delà les siècles. 